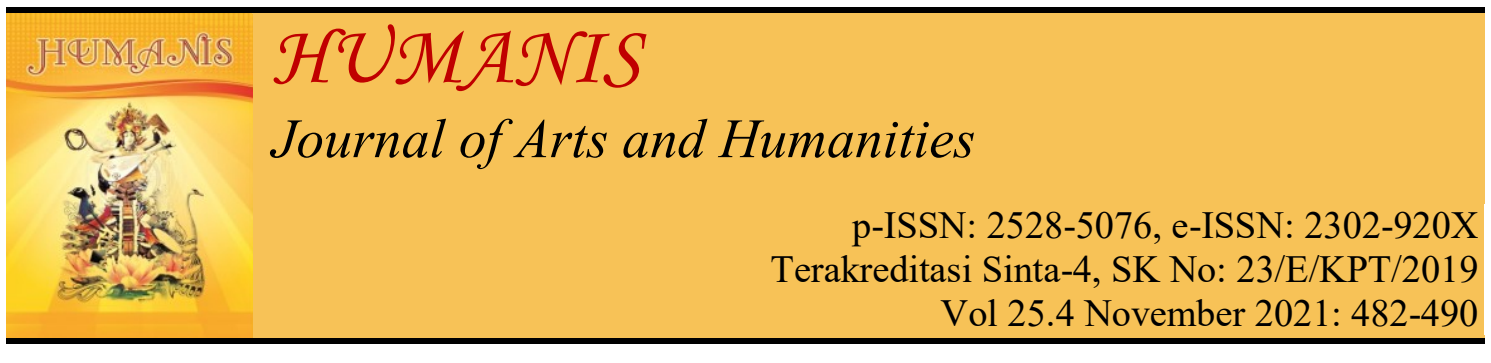

\title{
Transformasi Rumah Panggung Masyarakat Loloan Timur dalam Pemajuan Kebudayaan
}

\author{
Ni Made Wiasti, Ni Luh Arjani \\ Universitas Udayana, Denpasar, Bali \\ Email korespondensi: mwiasti@yahoo.com, luh_arjani@unud.ac.id
}

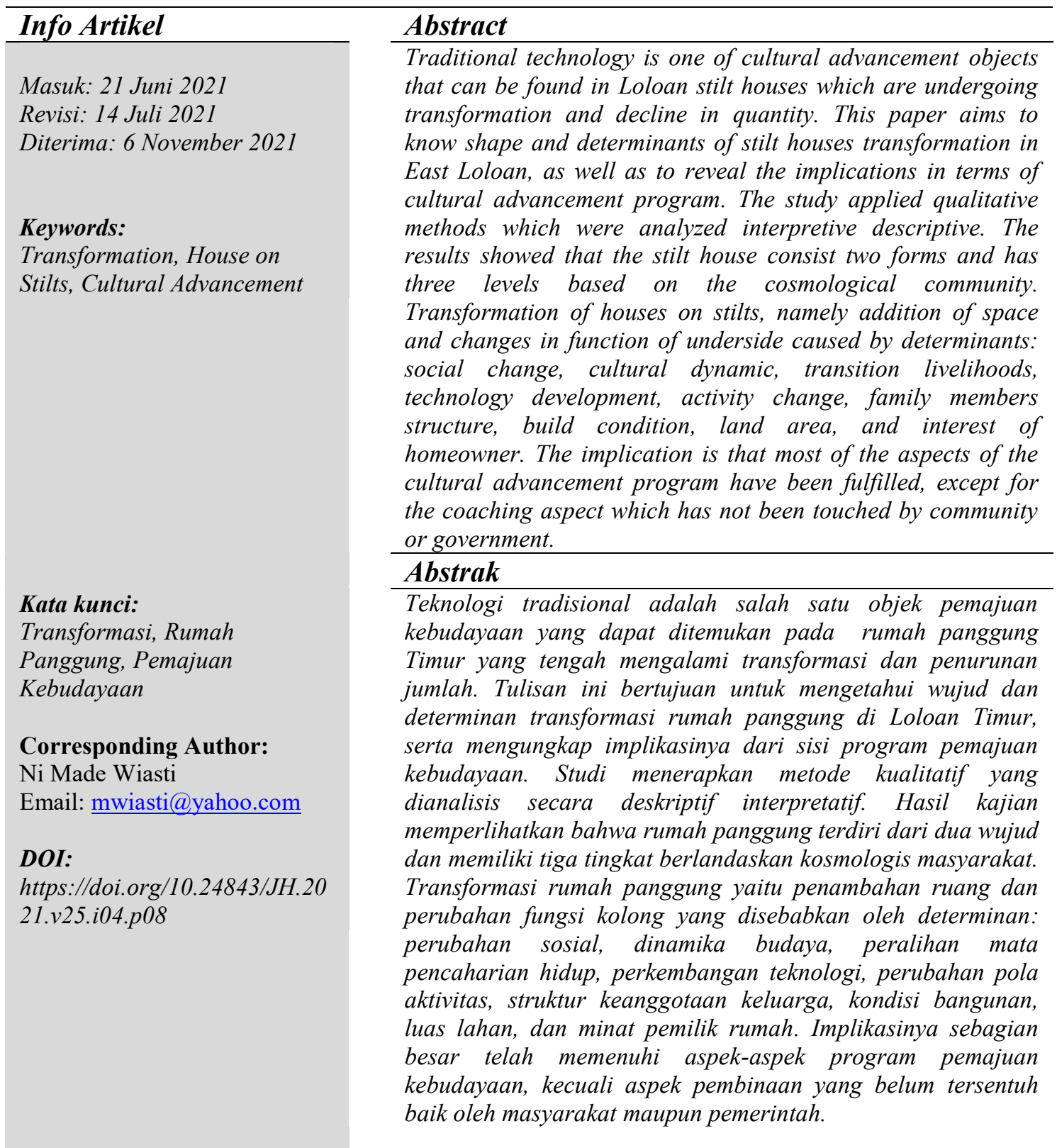




\section{PENDAHULUAN}

Program Pemajuan Kebudayaan yang telah disahkan dalam UndangUndang Nomor 5 Tahun 2017 menekankan bahwa teknologi tradisional merupakan satu diantara sepuluh objek pemajuan kebudayaan. Sebagai salah satu objek pemajuan kebudayaan, wujud teknologi tradisional dapat diperhatikan pada bangunan atau arsitektur rumah tradisional suatu masyarakat. Di Indonesia, dapat dijumpai beragam arsitektur rumah dari yang sudah modern bahkan masih mempertahankan bentuk tradisionalnya. Ashadi (2018: 61) menerangkan bahwa bangunan berbentuk panggung merupakan rumah tradisonal yang banyak tersebar di wilayah Indonesia. Keberadaan rumah dengan gaya arsitektur panggung ini pun bisa ditemukan di Loloan, Kabupaten Jembrana, Provinsi Bali. Selain dikenal sebagai daerah berkependudukan mayoritas agama Islam, masyarakat Loloan memiliki ciri khas pada bangunan rumah tradisionalnya berbentuk panggung, sebab keunikannya tersebut tidak dapat ditemukan dalam arsitektur rumah tradisional di Bali pada umumnya.

Seorang informan bernama Muztahidin menuturkan bahwa seluruh rumah di Loloan dahulu masih terbuat dari bahan alami seperti kayu dan gedek. Namun sekarang jumlah keberadaan rumah tersebut semakin berkurang. Berdasarkan hasil wawancara, jumlah rumah panggung yang masih bertahan di Kelurahan Loloan Timur yakni hanya 62 bangunan. Di samping itu, rumah-rumah tersebut telah bertransformasi, baik dari segi penggunaan bahan, tata ruang dan fungsinya. Transformasi pada rumah panggung Loloan dilatarbelakangi oleh berbagai macam faktor, diantaranya kejenuhan terhadap wujud rumah panggung, kebutuhan ruang tambahan karena jumlah penghuni bertambah dan sebagainya. Berdasarkan pemaparan atas fenomena tersebut, relevansi penelitian ini menjadi lebih baik ketika dikaitkan dengan program pemajuan kebudayaan, khususnya mengenai kontinuitas kebudayaan dengan menerapkan inventarisasi, pengamanan, pemeliharaan, penyelamatan dan publikasi. Kajian tulisan ini bertujuan untuk mengetahui wujud dan determinan transformasi rumah panggung di Loloan Timur, serta mengungkap implikasinya dari sisi program pemajuan kebudayaan.

\section{METODE DAN TEORI}

Penelitian menerapkan metode kualitatif yang menekankan pada teknik observasi, wawancara mendalam dan studi dokumen. Pengumpulan data melalui tahap-tahap, yaitu: penentuan lokasi penelitian di daerah Loloan, penentuan informan yang memahami rumah panggung Loloan, mengobservasi transformasi rumah panggung Loloan, mewawancarai informan mengenai rumah panggung Loloan dalam kaitannya dengan transformasi dan pemajuan kebudayaan, serta menelaah berbagai dokumen terkait. Analisis data dilakukan dengan teknik deskriptif kualitatif. Fenomena transformasi rumah panggung di Kelurahan Loloan Timur mengacu pada teori yang dikemukakan oleh Habraken (1982: 14) bahwa indikasi perubahan dapat dilihat dari adanya penambahan (addition), pengurangan atau dihilangkan (elimination), pergerakan atau perpindahan (movement).

\section{HASIL DAN PEMBAHASAN}

\section{Wujud Rumah Panggung di Loloan}

Rumah panggung yang dimiliki masyarakat Loloan luasnya berkisar antara 2 sampai 4 are yang terdiri atas dua wujud, yaitu persegi panjang dan persegi. Perbedaan antara kedua wujud tersebut dapat diperhatikan pada luas bangunannya atau penempatan kamar 
tidur yang berada di lantai dua. Rumah panggung Loloan memiliki ketinggian sekitar 5 sampai 6 meter yang terdiri dari tiga tingkat/lantai, yakni kolong, tengah dan loteng. Ketiga lantai tersebut dapat tersusun dengan kuat karena ditopang oleh 12 atau 16 tiang pondasi, serta tali rotan yang diikat di setiap kerangka bangunan rumah. Susunan bertingkat pada rumah panggung Loloan dilandasi oleh perspektif kosmologis masyarakat setempat tentang dunia atas, dunia tengah dan dunia bawah. Pernyataan tersebut diungkapkan pula oleh Shima (2006: 22) bahwa pada masyarakat tradisional kerap menganggap jika struktur jagad raya terdiri atas tiga lapisan alam, yaitu alam atas, alam tengah dan alam bawah. Nuansa keagamaan Islam yang dianut sebagaian besar masyarakat Loloan turut mengembangkan penafsiran mereka terhadap struktur rumah panggungnya, loteng atau dalam bahasa setempat disebut para-para diartikan sebagai "Keesaan Allah" sedangkan dua lantai di bawahnya dipandang sebagai "dua kalimat syahadat".

Pada tingkat dasar atau kolong, tidak terdapat dinding permanen untuk menutupi setiap sisi ruangan, sehingga ruangan ini merupakan ruang terbuka yang hanya terdiri susunan tiang-tiang pondasi rumah. Dahulu kolong berfungsi sebagai tempat penyimpanan kayu bakar atau kayu sisa bangunan, peralatan rumah tangga, alat-alat kerja, dan dijadikan sebagai tempat bekerja atau bersantai, serta adapula yang memfungsikannya sebagai kandang ternak. Selain itu, masyarakat Loloan pun mengatakan bahwa sebelum adanya drainase seperti sekarang, lantai kolong yang masih beralaskan tanah dikatakan berfungsi untuk menyerap genangan air hujan atau air sungai yang meluap di dekat pemukiman mereka (sungai Ijo Gading). Berikutnya pada lantai tengah atau akrab disebut bale merupakan ruangan yang lebih lama digunakan dibandingkan dua lantai rumah lainnya oleh penghuni untuk menjalani berbagai aktivitasnya seharihari. Terdapat dua buah tangga untuk mengakses lantai tengah, pertama berada di sisi depan rumah, kedua di belakang rumah yang menghubungkan antara kolong dengan dapur yang berada di lantai tengah. Lantai tengah ini secara horisontal terbagi menjadi tiga bagian, yakni belakang, tengah dan depan. Pada bagian belakang berfungsi sebagai dapur, bagian tengah untuk kamar tidur, sedangkan bagian depan merupakan ruang multifungsi sebagai tempat menjamu tamu, beribadah, bersantai, dan sering pula digunakan anak laki-laki untuk tidur. Selain itu pada bagian depan di lantai tengah terdapat ruang terbuka yang disebut amben (serambi) biasa untuk meletakkan alas kaki, menjemur dan sebagainya. Terakhir adalah lantai paling atas dalam tingkatan rumah panggung, masyarakat Loloan menyebutnya loteng atau para-para, dimana untuk mengakses loteng tersebut penghuni rumah akan menggunakan tangga yang tergantung di lantai loteng. Para-para berfungsi sebagai tempat menenun dan tempat penyimpanan benda pusaka maupun bahan makanan untuk keperluan upacara keagamaan, pada momen tertentu ruangan ini menjadi tempat memingit anak perempuan yang akan melaksanakan perkawinan.

Rumah-rumah panggung di Loloan pada mulanya tidak memiliki kamar mandi karena pemukiman mereka yang berada di dekat sungai Ijo Gading. Masyarakat setempat dahulu memanfaatkan air sungai tersebut untuk kebutuhan sehari-harinya. Namun, kondisi sungai yang telah mengalami pelurusan dan penataan mengharuskan mereka tidak lagi melakukan aktivitas seperti MCK di sungai, oleh sebab itu di setiap rumah panggung Loloan sekarang sudah tersedia kamar mandi yang terletak 
di sisi belakang kolong. Selain itu, hasil pengamatan menemukan pula adanya penambahan ruang baru di luar struktur utama rumah panggung, seperti garasi, gudang, teras, ruang tamu, kamar tidur, gerai usaha dan dapur. Rumah panggung di Loloan secara keseluruhan telah mengalami penambahan ruang baru yang terjadi di luar struktur utama, dan jika ditinjau dari segi aspek tata ruang rumah panggung tradisional Loloan dapat disimpulkan bahwa terdapat ruang yang masih tetap bertahan dan ada pula yang telah berubah.

\section{Determinan Transformasi Rumah Panggung pada Masyarakat Loloan}

Pada sub pembahasan ini akan memaparkan determinan yang melatarbelakangi munculnya berbagai tipe rumah panggung yang ada sekarang di Kelurahan Loloan Timur, yakni:

1) Determinan Perubahan Sosial: manusia turut mengikuti perkembangan zaman dalam hal menjalin relasi sosial, beberapa penghuni rumah Loloan beranggapan kurang nyaman dan tidak sopan ketika berinteraksi di serambi yang terletak di sisi depan rumah dengan kondisi ruang terbuka dan berada dekat dengan jalan yang dilalui kendaraan. Keadaan tersebut menyebabkan penghuni rumah lebih memilih berinteraksi di ruang depan yang lebih tertutup, sehingga serambi semakin sempit atau bahkan dihilangkan.

2) Determinan Dinamika Budaya: dinamika budaya serta alasan tertentu menyebabkan beberapa tradisi yang dahulu dapat dijumpai di Loloan, sekarang mulai memudar atau bahkan sudah tidak diteruskan. Tradisi-tradisi yang dimaksud, seperti mencuci kaki di serambi ketika hendak masuk ke dalam rumah, tradisi memingit anak perempuan menjelang perkawinan dan penyimpanan benda pusaka di loteng rumah panggung. Dinamika budaya masyarakat turut mempengaruhi keberadaan ruang yang semula digunakan untuk mengaktualisasikan tradisi-tradisi tersebut, tetapi kini dihilangkan atau digantikan dengan ruang baru karena penghuni rumah menganggap ruang sebelumnya sudah tidak berfungsi.

3) Determinan Peralihan Mata Pencaharian Hidup: sejak kedatangannya ke Bali, masyarakat Loloan dikenal sebagai komunitas yang selalu bersentuhan dengan kemaritiman. Dalam melangsungkan hidup, bekerja sebagai nelayan banyak dilakoni masyarakat Loloan, sehingga kolong rumah panggung kerap dimanfaatkan untuk menambatkan perahu, menyimpan alat kerja dan sekaligus tempat memperbaiki jala. Dewasa ini, profesi nelayan banyak yang mulai meninggalkannya, masyarakat Loloan cenderung memilih menjadi karyawan swasta, tenaga pendidik atau bekerja di sektor niaga dan sebagainya, sehingga peralihan mata pencaharian hidup masyarakat turut mempengaruhi perubahan fungsi pada rumah panggung khususnya kolong, misalnya beralih menjadi kamar tidur, ruang tamu, warung dan dapur. Namun, bagi sebuah keluarga yang belum memiliki cukup anggaran dana akan memilih tetap mempertahankan wujud rumah panggungnya.

4) Determinan Perkembangan Teknologi: ketersediaan bahan-bahan material baru yang banyak digunakan sekarang tidak lepas dari pengaruh perkembangan teknologi. Bahan modern tersebut menjadi alternatif pemilik rumah untuk mengganti atau mendukung bahan yang sudah lapuk/rusak, contohnya agar bangunan rumah menjadi lebih kokoh maka penghuni menambahkan dinding dari bahan bata untuk menopang tiang kayu yang telah lapuk, dan penggunaan material yang lebih murah serta awet seperti seng untuk mengganti gedek yang sering mengeluarkan kotoran bubuk. 
5) Determinan Perubahan Pola Aktivitas: pada masyarakat Loloan terdapat aktivitas yang sudah tidak dilakukan sehingga menyebabkan beberapa ruang yang dahulu digunakan untuk mewadahi aktivitas tersebut dihilangkan, seperti loteng dan serambi. Pemilik rumah cenderung menghilangkan kedua ruangan tersebut karena aktivitas yang dilakukan di ruangan ini sudah tidak dilakukan. Sebaliknya, mereka akan menambah beberapa ruang untuk mewadahi perubahan pola aktivitasnya, antara lain membuat ruang tamu, ruang untuk tempat usaha, dan garasi atau tempat parkir kendaraan.

6) Determinan Struktur Keanggotaan Keluarga: bertambahnya anggota dalam suatu keluarga yang menghuni sebuah rumah panggung menyebabkan penghuni rumah perlu mengembangkan kebutuhannya terhadap ruang, yakni kamar tidur. Oleh sebab itu, struktur keanggotaan keluarga berpengaruh terhadap kemunculan ruang-ruang tambahan seperti kamar tidur dan ruang keluarga yang diperluas.

7) Determinan Kondisi Bangunan: kondisi bangunan rumah panggung yang telah lapuk/rusak dan berusia tua menyebabkan kekhawatiran terhadap pemilik rumah. Kekhawatiran tersebut sering ditujukan terhadap tiang-tiang kayu yang telah ratusan tahun menopang bangunan, sehingga upaya penghuni rumah adalah menambahkan dinding permanen minimal di setiap sisi kolong rumah panggung agar ikut menyangga pondasi bangunan terutama pada bagunan di lantai tengah dan loteng.

8) Determinan Luas Lahan: perluasan infrastruktur yang dibangun berupa trotoar dan jalan raya oleh suatu daerah, menyebabkan pengurangan lahan di bagian depan rumah panggung, sehingga berdampak terhadap penempatan tangga yang semula di depan rumah panggung, namun kini ditempatkan di samping rumah panggung. Sedangkan sisa lahan di bagian depan dan samping rumah panggung, dimanfaatkan menjadi ruangruang baru seperti ruang tamu, dapur, teras, ruang untuk tempat usaha, dan garasi atau tempat parkir kendaraan.

9) Determinan Minat Pemilik Rumah Panggung: minat yang dimaksud adalah keinginan pemilik rumah untuk mengikuti dengan cara meniru suatu bentuk bangunan rumah yang berbeda. Keinginan tersebut biasanya muncul karena dilatarbelakangi oleh perasaan jenuh terhadap sesuatu yang bersifat lampau, sehingga wujud setiap rumah panggung di Loloan sekarang beraneka ragam karena setiap pemilik rumah ingin memiliki rumah yang berbeda dengan rumah tetangganya.

Jika dicermati, kesembilan determinan yang melatarbelakangi transformasi rumah panggung tersebut sesungguhnya telah sesuai dengan ide yang terkandung dalam Undang-Undang Pemajuan Kebudayaan terutama jika dikaitkan dengan aspek: perlindungan, pengembangan, dan pemanfaatan, hanya aspek pembinaan belum tampak, baik yang dilakukan oleh masyarakat, maupun pihak pemerintah terhadap keberadaan rumah panggung di Kelurahan Loloan Timur.

\section{Implikasi Transformasi Rumah Panggung Loloan dalam Program Pemajuan Kebudayaan}

Pada program pemajuan kebudayaan terdapat empat aspek penting, antara lain: Perlindungan, Pengembangan, Pemanfaatan, dan Pembinaan. Berkenaan dengan rumah panggung Loloan yang telah bertransformasi sesuai pembahasan sebelumnya, maka kaitannya dalam program pemajuan kebudayaan dapat dijelaskan sebagai berikut.

1) Aspek Perlindungan adalah upaya untuk menjaga kesinambungan 
kebudayaan melalui inventarisasi, pengamanan, pemeliharaan, penyelamatan, dan publikasi. Menurut seorang informan bernama Muztahidin, masyarakat Loloan pada mulanya memiliki rumah panggung, tetapi seiring perjalanan waktu jumlahnya terus menurun. Berdasarkan catatan tahun 2013, rumah panggung Loloan berjumlah 63 unit, namun tahun 2020 turun drastis menjadi 40 unit bahkan itu pun telah mengalami transformasi baik dari segi wujud dan fungsi.

Transformasi tersebut muncul dari berbagai determinan seperti yang telah diuraikan pada pembahasan sebelumnya. Walau telah mengalami transformasi, masyarakat Loloan masih menyebut rumah mereka dengan sebutan rumah panggung selama rumah itu masih mempertahankan tiga lantai atau tingkatan pada susunan rumah. Jika perubahan telah mencapai pada level penghilangan salah satu lantai, maka bangunan tersebut tidak lagi disebut rumah panggung. Para pemuda-pemudi di Loloan dalam praktiknya telah melakukan pemeliharaan dan penyelamatan terhadap rumah panggung Loloan dengan menyelenggarakan berbagai program, antara lain penyelenggaraan festival budaya bertajuk "Loloan Jaman Lame" yang diadakan setiap tahun dan sosialisasi kepada masyarakat Loloan khususnya generasi muda baik secara langsung maupun melalui media sosial.

2) Aspek Pengembangan adalah upaya untuk meningkatkan kebertahanan, memperkaya, keragaman, dan menyebarluaskan kebudayaan. Informasi dari Kepala Lingkungan Loloan Timur menjelaskan bahwa pemukian di Kelurahan Loloan Timur dulunya semua adalah rumah panggung yang menggunakan bahan material alami. Namun wujud rumah panggung sekarang telah bertransformasi baik dari segi bahan material dan tata ruang. Hanya beberapa dari masyarakat setempat yang masih mempertahankan wujud asli rumah panggung Loloan karena keterbatasan finansial untuk melakukan transformasi terhadap rumah panggungnya.

3) Aspek Pemanfaatan adalah upaya memberdayakan objek pemajuan kebudayaan untuk menguatkan ideologi eko-sosio-kultural, pertahanan, keamanan dan politik sebagai wujud dari tujuan nasional. Dari empat aspek program pemajuan kebudayaan, pemanfaatan merupakan aspek yang paling mendominasi rumah panggung Loloan, khususnya pada lantai kolong. Transformasi pada kolong rumah panggung Loloan didasari oleh struktur keanggotaan keluarga dan peralihan profesi masyarakat Loloan yang dulu sebagai nelayan, namun sekarang beralih ke perniagaan, kepegawaian dan sektor lainnya, sehingga menyebabkan kolong rumah yang digunakan untuk menambatkan perahu dan menyimpan peralatan sudah tidak berfungsi, namun beralih fungsi menjadi tempat berniaga, ruang tamu, kamar tidur, dan sebagainya.

4) Aspek Pembinaan adalah upaya pemberdayaan yang dilaksanakan oleh suatu lembaga maupun pranata kebudayaan seperti masyarakat yang berperan aktif dan inisiatif melakukan pembinaan. Berdasarkan hasil wawancara terhadap seorang tokoh pemuda Loloan, menjelaskan bahwa rumah panggung Loloan kerap menjadi ajang perebutan oleh para pewaris, selain itu pemeliharaan rumah panggung Loloan membutuhkan biaya cukup tinggi. Hal tersebut sangat memberatkan, sehingga banyak yang mengambil keputusan menjual bangunan rumah panggung tersebut agar hasil penjualan dapat dibagikan kepada para pewaris sebagai modal membangun rumah modern. Ada banyak rumah panggung yang telah dijual ke Jerman atau Belanda, sehingga 
bisa saja kelak orang Loloan yang ingin melihat rumah panggungnya harus pergi ke dua negara tersebut. Berkenaan untuk mengatasi permasalahan tersebut, masyarakat Loloan dijanjikan sejumlah anggaran oleh pemerintah pada tahun 2020, tetapi batal karena sebagian besar anggaran pemerintah dialihkan untuk penanggulangan Coronavirus disease 2019. Di sisi lain, upaya yang dilakukan oleh para tokoh masyarakat dan agama hanya mampu sebatas pemberian imbauan, karena permasalahan tersebut menyangkut urusan warisan keluarga.

Berdasarkan uraian tersebut di atas, maka dapat ditarik suatu simpulan bahwa keberadaan rumah panggung Loloan sekarang jumlahnya sudah sangat mengkhawatirkan. Rumah tersebut mudah diperjualkan karena berasal dari bahan material alami yang bernilai jual fantastis. Salah satu hal yang paling mendasari penurunan jumlah rumah panggung Loloan karena berkenaan dengan persoalan warisan dan permasalahan ekonomi yang mendesak, sehingga menjual rumah panggung peninggalan orang tua dianggap menjadi sebuah solusi untuk memediasi ketegangan perebutan warisan dan mengatasi masalah ekonomi. Jika fenomena ini dikaitkan dengan program pemajuan kebudayaan yang meliputi empat aspek: perlindungan, pengembangan, pemanfaatan, dan pembinaan tampaknya kurang selaras. Oleh sebab itu, strategi yang dapat dilakukan secara konkrit oleh berbagai pihak terkait: pihak pemerintah baik di tingkat pusat maupun daerah dalam merealisasikan UU Pemajuan Kebudayaan, pihak swasta dalam hal dukungan, dan masyarakat Loloan yang berperan penting sebagai pelaku budaya yang bersentuhan langsung dengan rumah panggung Loloan. Karena jika tidak, bisa saja rumah panggung Loloan hanya menyisakan kenangan.

\section{SIMPULAN}

Berdasarkan pemaparan dalam pembahasan, maka dapat disimpulkan tiga hal sebagai berikut. 1) rumah panggung Loloan terdiri dari dua wujud yakni persegi dan persegi panjang menyesuaikan pada kepemilikan lahan. Rumah panggung Loloan memiliki tiga tingkat berlandaskan pada perspektif masyarakat dan ajaran agama Islam, yaitu kolong atau disebut siring, lantai tengah yang disebut bale, dan loteng disebut para-para. 2) transformasi rumah panggung Loloan dilatarbelakangi beberapa determinan: perubahan sosial, dinamika budaya, peralihan mata pencaharian hidup, perkembangan teknologi, perubahan pola aktivitas, struktur keanggotaan keluarga, kondisi bangunan, luas lahan, dan minat pemilik rumah panggung Loloan. 3) implikasi transformasi rumah panggung Loloan sudah sesuai dengan program pemajuan kebudayaan yang meliputi aspek perlindungan, pengembangan, pemanfaatan, kecuali aspek pembinaan yang belum tampak.

Berdasarkan pemaparan di atas, dapat diajukan beberapa saran yaitu: Rumah panggung yang berada di Loloan sangat memerlukan tindakan konkrit yang strategis oleh para pihak. Perlu suatu tindakan untuk merawat rumah panggung yang masih ada dengan menjaga keadaan aslinya tanpa adanya perubahan sehingga dapat mencegah kehancuran. Kebijakan Pemerintah Kabupaten Jembrana dalam berperan untuk melestarikan situs rumah panggung sangat diharapkan. Upaya pemerintah untuk memfasilitasinya melalui Program Nasional Pemberdayaan Masyarakat (PNPM) Mandiri, misalnya, diharapkan turut mengatasi kesulitan biaya yang selama ini menjadi ganjalan bagi para pemilik rumah panggung. Perlu dilakukan upaya membuat rumah panggung sebagai rumah percontohan 
agar masyarakat dan generasi selanjutnya masih dapat melihat rumah panggung masyarakat Loloan dalam wujud aslinya.

\section{DAFTAR PUSTAKA}

Acwin Dwijendra. (2009). Ngakan Ketut. Arsitektur dan Kabudayaan Bali Kuno. Denpasar: Udayana University Press

Angkasa, Zuber. (2017). "Penerapan Konsep Arsitektur Rumah Panggung di Lingkungan Perkotaan". Jurnal Arsir Vol. 1 No. 2, Desember: 175183.

Anonim. (2003). Himpunan Asal-usul / Sejarah Singkat Desa / Kelurahan di Kabupaten Jembrana.

Ashadi. (2018). Pengantar Antropologi Arsitektur. Jakarta: Arsitektur UMJ Press.

Danandjaja, James. (1985). Upacaraupacara Lingkaran Hidup di Trunyan, Bali (Life Cycle Ceremonies in Trunyan, Bali). Jakarta: PN Balai Pustaka.

Goo, A. Andreas. (2012). Kamus Antropologi. Jayapura: Lembaga Studi Meeologi.

Habraken, N.J. (1982). Transformation of the Site. Cambridge: Massachusetts Summer.

Hamka, dkk. (2015). "Karakteristik Orientasi Rumah Tradisional Bugis (Bola Ugi) di Dusun Kajuara Kabupaten Bone Sulawesi Selatan". Jurnal Langkau Betang Vol. 2 No. 2: 94-107.
Hendraningsih. (1985). Peran, Kesan dan Pesan Bentuk Arsitektur. Jakarta: Djambatan.

Heryati. (2011). "Nilai-nilai Sejarah dan Filosofi Pada Arsitektur Rumah Panggung Masyarakat Gorontalo". Jurnal Inovasi Vol. 8 No. 2, Juni: 237-254.

Humprey, C. (1983). "No Place Like Home in Anthropology: The Neglect of Architecture, Anthropology Today 4 (1): 16-18.

Koentjaraningrat. (1987). Manusia dan Kebudayaan di Indonesia. Jakarta: Djambatan.

Maryono, Irawan dkk. (1985). Pencerminan Nilai Budaya dalam Arsitektur di Indonesia. Jakarta: Djambatan.

Mattulada. (1971). "Kebudayaan Bugis Makassar", dalam Koentjaraningrat (ed.), Manusia dan Kebudayaan di Indonesia. Jakarta: Penerbit Djambatan.

Mattulada. (1985). Latoa: Satu Lukisan Analitis Terhadap Antropologi Politik Orang Bugis. Yogyakarta: Gajah Mada University Press.

Maulida, Nurus. (2017). "Pemertahanan Identitas Etnik Bugis-Melayu di Kelurahan Loloan, Kecamatan Negara, Kabupaten Jembrana, Bali dan Potensinya sebagai Sumber Belajar Sejarah di Ma". Widya Winayata: Jurnal Pendidikan Sejarah Vol. 8, No. 2.

Pujaastawa, Ida Bagus Gde. (2019). Pengembangan Ekonomi Kreatif Berbasis Pengetahuan Tradisional Sebagai Wahana Pemajuan 
Kebudayaan, Makalah disampaikan pada Seminar Nasional "Pengembangan Ekonomi Kreatif Berbasis Budaya Lokal sebagai Alternatif Strategi Pemajuan Kebudayaan". Denpasar, 31 Juli 2019.

Purna, I Made. (2016). Tradisi Bali Aga di Desa Adat Sidatapa, Kecamatan Banjar, Kabupaten Buleleng - Bali. Denpasar: Kepel Press.

Riany, Meta, dkk. (2014). "Kajian Aspek Kosmologi-Simbolisme Pada Arsitektur Rumah Tinggal Vernakular di Kampung Naga". Jurnal Reka Karsa No. 2 Vol 2 Desember.

Rumiawati, Asnah dan Yuri Hermawan Prasetyo. (2013). "Identifikasi Tipologi Arsitektur Rumah Tradisional Melayu di Kabupaten Langkat dan Perubahannya". Jurnal Permukiman Vol. 8, No. 2, Agustus: 78-88.

Saptandari, Pinky. (2019). Ekonomi Kreatif Berbasis Budaya Lokal: Strategi Pemajuan Kebudayaan Indonesia, Makalah disampaikan pada Seminar Nasional "Pengembangan Ekonomi Kreatif Berbasis Budaya Lokal sebagai Alternatif Strategi Pemajuan Kebudayaan". Denpasar, 31 Juli 2019.

Satori, Djaman dan Aan Komariah. (2009). Metodologi Penelitian Kualitatif. Bandung: Alfabeta.

Shima, N. Palemmui. (2006). Arsitektur Rumah Tradisional Bugis. Makassar: Badan Penerbit UNM.
Undang-undang Republik Indonesia Nomor 5 Tahun 2017 tentang Pemajuan Kebudayaan. 